\title{
DesactivaÇão e Regeneração de Catalisadores
}

POR Michel Guisnet, Henrique S. Cerqueira, José Luís Figueiredo e Fernando Ramôa Ribeiro

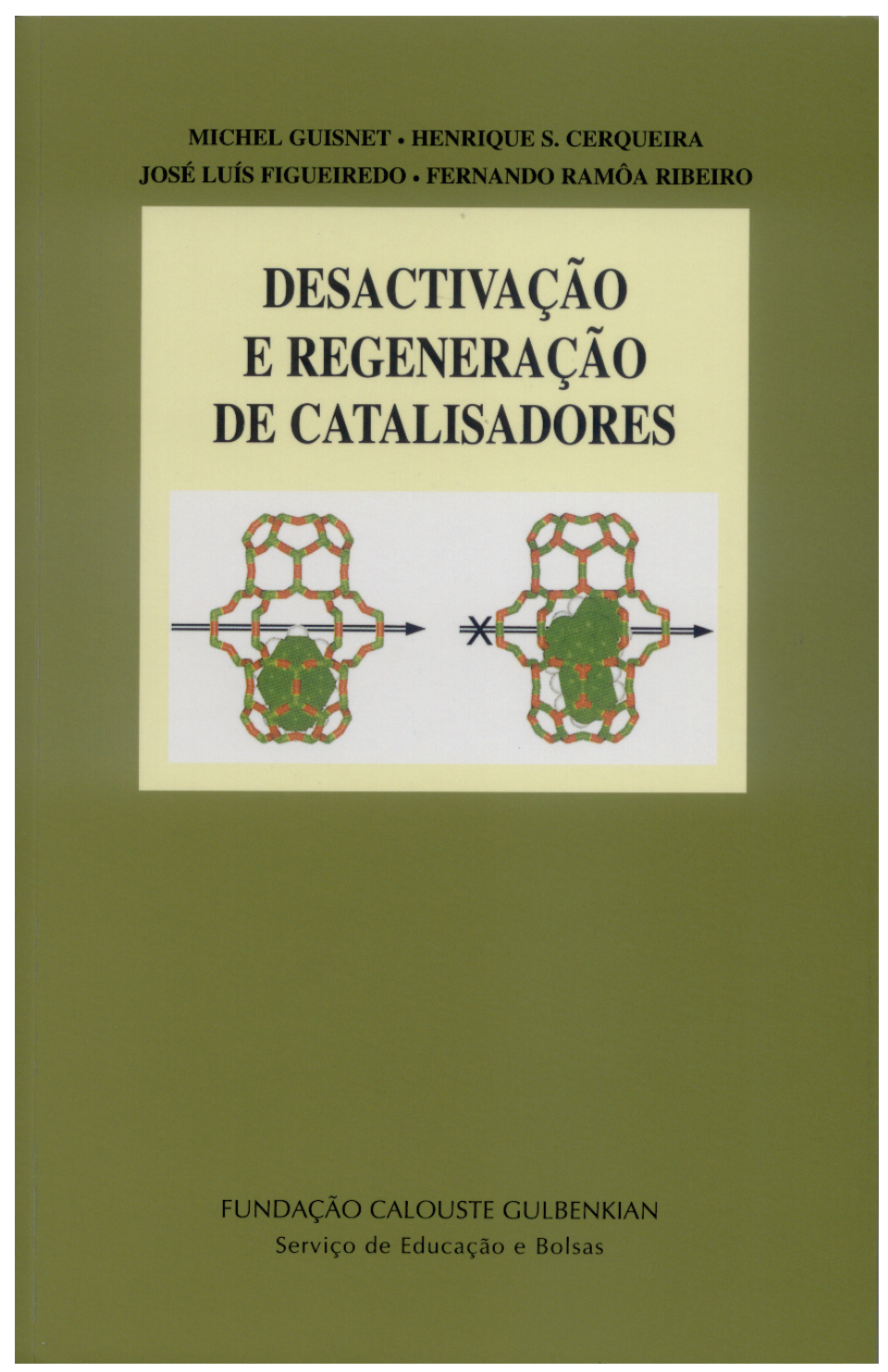

Excertos do Prefácio, da Autoria do Doutor Eduardo Falabella SOUSA-AgUIAR

Embora a desactivação de catalisadores seja um fenómeno cuja importância cresce a partir da observação de ocorrências industriais, este livro não se resume a discutir o "apenas observado". Os seus vários capítulos procuram, de maneira excepcionalmente didáctica, revelar a essência do fenómeno da desactivação de catalisado- res tanto heterogéneos, o que é mais usual, quanto homogéneos, numa tentativa inovadora de abranger todos os campos da Catálise.

Caro leitor, esteja seguro de que se depara com um livro didáctico de excelente qualidade, capaz de não só conduzir de forma clara e objectiva os neófitos no campo da desactivação, revelando um universo desconhecido e fascinante, como também de ajudar aqueles que já trabalham na área, seja nas indústrias, seja em laboratórios de investigação. É uma publicação pioneira em língua portuguesa, pelo que, indubitavelmente, em muito colaborará com os professores universitários que ministram cursos de Catálise, Cinética, Reactores e Processos Catalíticos. 


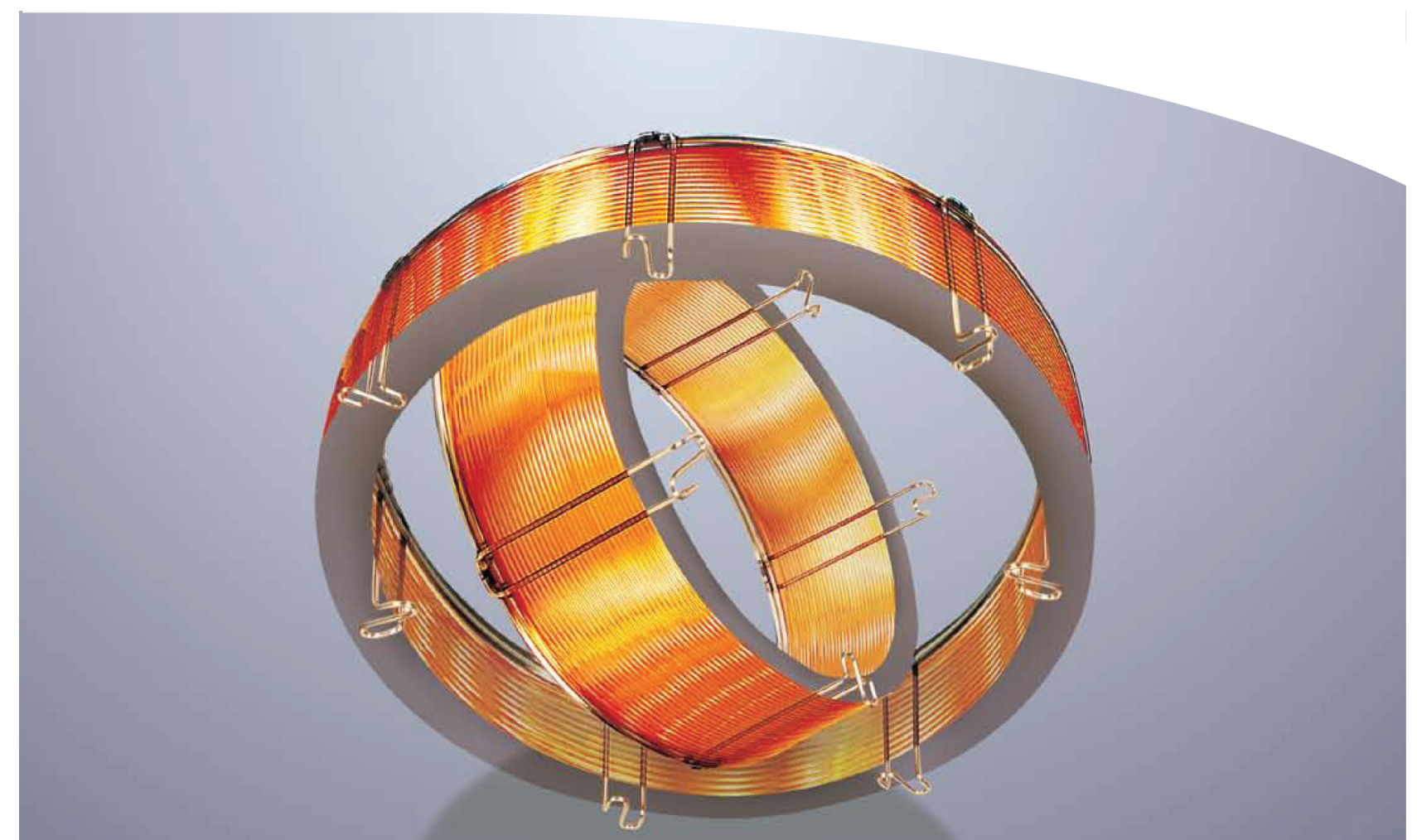

\section{Innovation Comes In Many Forms}

Zebron - Revolutionizing the Field of Gas Chromatography

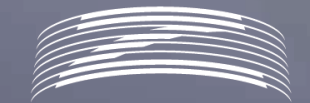

Zetion

\begin{tabular}{ll}
\hline Zebron " ZB-WAX pLUS: & Ideal for polar compounds . 100\% aqueous stable. \\
\hline Zebron MultiResidue " : & $\begin{array}{l}\text { Perfect for pesticide analysis .For US EPA 8081A, } \\
\text { baseline resolution is achieved in just } 10 \text { minutes! }\end{array}$ \\
\hline $\begin{array}{l}\text { Zebron ZB-1HT Inferno } \\
\text { and ZB-5HT Inferno : }\end{array}$ & $\begin{array}{l}\text { The world's highest temperature non-metal GC } \\
\text { columns. Provides true boiling point separation } \\
\text { for hydrocarbon distillation methods. }\end{array}$ \\
\hline
\end{tabular}

Zebron has been revolutionizing the field of gas chromatography with its commitment to producing innovative, high quality columns that meet the needs of today's gas chromatographers. Our scientists have developed key technologies, such as Engineered Self Cross-linking " (ESC) and Arylene Matrix Technology " (AMT), to create GC columns that provide high temperature stability, improved lifetime, low bleed, and low activity. Each and provide high temperature stability, improved lifetime, low bleed, and low activity. Each and
every column is individually QC tested to ensure that they have excellent batch-to-batch reproducibility so you will have reliable and reproducible results, every time. For a column that reproducibility so you will have reliable and reproducible results, every time.
best meet your needs, please contact your local Phenomenex Technical Specialist.

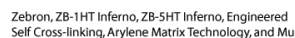

enex,IInc.All rights reserved

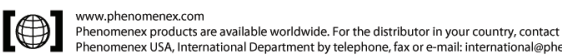

Pohenomenex"

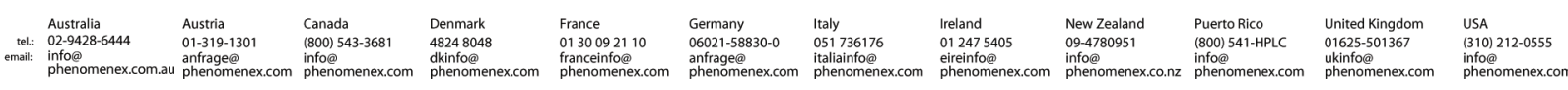

